\title{
AN ANALYSIS OF RELATIVE CLAUSES MADE BY THE EIGHT GRADE STUDENTS OF SMP NEGERI 3 SELAT IN ACADEMIC YEAR 2017/2018
}

\author{
Ni Made Lisma Martarini \\ STMIK STIKOM Indonesia \\ Email: lismamartarini@gmail.com
}

\begin{abstract}
The present study is dealt with An Analysis of Relative Clauses Made by the Eight Grade Students of SMP Negeri 3 Selat in Academic Year 2017/2018. The researcher was interested in making an analysis of Relative clauses made by the students under study. The present study is intended to assess the acquisition of relative clauses made by the eighth-grade students of SMP N 3 Selat Karangasem in academic year 2017/2018. In other words, this study is to figure out the ability of the subject under study in understanding relative clauses. The present's study which use ex-post facto research design with descriptive analysis was intended to answer the following research question: to what extent is the acquisition of relative clauses made by the eighth-grade students of SMP N 3 Selat Karangasem in academic year 2017/2019? In order to answer the research question before, the data were required for the present study which in the form of raw score is showing the ability of the students in mastering relative clauses, were collected by administering the valid and reliable research instrument in form of multiple-choice test items. Then the data is analyzed by using Norm-Reference measure with five standard values. The populations of the present study are the eighth-grade students of SMP Negeri 3 Selat which consist of 206 students. They are considered to have heterogeneous characteristics. In this study 30 students are considered as a sample of the study by using random sampling technique. The data of the study is clearly showed that: (1) there are 4 students or $(13.33 \%)$ out of 30 students under study who showed excellent ability of relative clauses. (2) There are 4 students or (13.33\%) out of 30 students under study who showed good ability of relative clauses (3) there are 10 students or $(33.33 \%)$ out of 30 students under study who showed sufficient ability of relative clauses. (4) There are 12 students or (40\%) under 30 students under study who showed insufficient ability of relative clause. (5) No one students or $(0 \%)$ out of 30 students who showed poor ability of relative clauses. In the result of the study were used as the basses to assign level/grade to the subject under study, there are 12 students or $40 \%$ out of 30 students under investigation who fail in learning and acquiring relative clauses. It means that $40 \%$ of them still have low ability. The finding of the present study can be used as the basses in planning much better language teaching especially in mastering grammar or relative clauses.
\end{abstract}

Key word: analysis, relative clauses 


\section{INTRODUCTION}

Grammar must not be seen as something which is in central organizing principle of communication. It means that grammar has a central role in language teaching. In applied the significance of grammar as an integral component of language teaching, in this opportunity the researcher decides to investigate the relative clauses as one important structural component of English.

Relative clause is a part of a sentence, which is tell us about which is person of thing or what kind of person or thing that the speaker means (Hewings,2002:174). The other word, a relative or adjective clause is a dependent clause which functions as an adjective. That is, it modifies or gives more information about a noun or pronoun. The relative clauses have been taught intensively because it has some part; relative pronoun and relative adverbial clauses. Relative pronouns allow you to show the relationship between a subordinate clause and the main clause. The main clause is always the one that can stand alone, while the subordinate clause cannot. A relative pronoun links the two. Of course, since these words are pronouns, they just as all other pronouns can stand in for nouns (Dutwin,2010:67).

Practical attempt and measure to help students acquire relative clause should be based on the real analysis which are faced by the classroom teacher and students. Relative clause as a part of grammar should be taught in well by students, because grammar as a fundamental part in creates a good sentence and it also influencing for someone in mastering other skill. Especially in Indonesia, the student's ability in understanding grammar is still low due the teaching facilities, the teacher teaching method which is not interest for students, and so on. According to that statement, the researcher is decided to study about the analysis of relative clause made by the eighthgrade students of SMP N 3 Selat Karangasem in academic year 2017/2018.

\section{Statement of Research Question}

According to that fact, the researcher wants to examine the following research question: to what extent is the acquisition of relative clauses made by the eighth-grade students of SMP N 3 Selat Karangasem in academic year 20017/2018?

\section{Objective of the Study}

The objective of the study is to answer or solve the research question which has been explained for the study. The present study is intended to assess the acquisition of relative clauses made by the eighth-grade students of SMP N 3 Selat Karangasem in academic year $2017 / 2018$. In other words, this study is to figure out the ability of the subject under study in understanding relative clauses.

\section{Kinds of Relative Clause}

There are some types of relative pronoun as the connector in 
make relative clause. Some examples of the most common types are: relative pronoun as subject, relative pronouns as object, relative pronoun as object of prepositions, relative pronouns in phrases of quantity, possessive relative clauses, and relative adverbial clauses.

\section{A. Relative Pronouns as Subject}

The examples of relative clause as subject are: People want to save time and energy, they use microwave ovens. Those sentences combined altogether became People who use microwave oven want to save time and energy. The other example is: Ovens use microwave energy, they are capable of cooking food quickly. Those sentences combined altogether became: Oven that are capable of cooking food quickly use microwave energy.

\section{B. Relative Pronoun as Object}

Azar (2011:268) states that, some examples of relative clause as object are formed in this example:

a. The man whom I saw is Mr. Jones

b. The man that I Saw is Mr Jones

In that example is the adjective clause pronouns are placed at the beginning of the clause. In the example (a) who is usually used instead of whom especially in speaking. Whom is usually uses in very formal English. In the example (b), that is has same function as whom, because that is used for both or things, and who is uses for people. The relative pronoun whom and that is called relative clause as object because it functions as the object of the verb saw.

\section{Relative Pronoun as Object of Preposition}

A relative pronoun can be the object of preposition in its own clause. The relative pronoun that can only be used in the informal pattern (preposition at the end of the clause) in restrictive clauses. The examples of relative pronoun as object of preposition are as follows: The candidates did not win the election, I voted for the candidate. Those sentences combine altogether became: (The candidates for whom I voted didn't win the election) or (The candidates whom I voted for didn't win the election) or (The candidates that I voted didn't win the election). The other example is like this: The names of the victim are unknown; this monument was built in the victim' memory. That statement is combined altogether became: (The names of the victim in whose memory this monument was built are unknown.)

D. Relative Pronoun in Phrase of Quantity

The examples of relative pronoun in phrase of quality are: The members of the special commission on crime meet weekly, some of them were appointed by the major. Those sentences are combined became: (The members of the special commission on crime, some of whom were appointed by mayor, meet weekly). The other example is: As an experiment, television station decided to show only movies, I had already seen most of the movie. Those 
sentences are combined became: (As an experiment, the television station decided to show only movie, most of which I had already seen).

\section{Research Design}

The present study which deals with analysis of relative clauses made by the eighth-grade students of SMP N 3 Selat Karangsem in academic year 2017/2018, may use ex-post facto research design with descriptive analysis. Ary, (2010:332) defines that in ex-post facto research, the researchers do not permit the randomization and manipulation of variables characteristic of experimental research. Cohen (2000: 205) also said that Ex post facto research is a method of teasing out possible antecedents of events that have happened and cannot, therefore, be engineered or manipulated by the investigator. In an ex post facto investigation, in contrast, the researcher cannot control the independent variables by manipulation or by randomization or changes in the variables have already taken place. Moreover, inferences about relation among variables are made without direct intervention from concomitant variation of independent and dependent variable. In ex-post facto research, it is simply not feasible for the researcher to manipulate or control the examined variables

\section{Population and Sample}

The eight grade students of SMPN 3 Selat in academic year 2017/2018 which total 7 classes with
206 students altogether are consider as the population of the present study. In general, the populations are regarded to have rather homogeneous characteristics in the term of some traits, such as socio-economic background, age, learning motivation, intelligence, aptitude and attitude toward English. In this study, the sample must be taken into the smaller group which is obtained from the larger group called population. Sample is a part of population that might be taken or the small group that is reachable and capable of being observed in a little amount. In states sample, is taken $10 \%$ until $15 \%$ with the population more than 100. In this study, 30 students are determined as the samples by using of random sampling technique with lottery system. The samples are assumed to be representative enough, and the selection of a representative sample suggests that the finding of the study can be more generalized to the target population

\section{RESULT}

The interpretation of the results of data analysis, as tabulated above clearly showed that (1) there are 4 students out of 30 students under study who showed excellent ability of relative clauses. (2) There are 4 students out of 30 students under study who showed good ability of relative clauses (3) there are 10 students out of 30 students under study who showed sufficient ability of relative clauses. (4) There are 12 students under 30 students under study who showed insufficient ability 
of relative clause. (5) No one students out of 30 students who showed poor ability of relative clauses. In the result of the study were used as the basses to assign level/grade to the subject under study, there are 12 students or $40 \%$ out of 30 students under investigation who fail in learning and acquiring relative clauses. It means that $40 \%$ of them still have low ability.

\section{CONCLUSIONS}

The conclusions throughout the present study can concluded as the following: There are 4 students out of 30 students under study who showed excellent ability of relative clauses. There are 4 students out of 30 students under study who showed good ability of relative clauses. There are 10 students out of 30 students under study who showed sufficient ability of relative clauses. There are 12 students under 30 students under study who showed insufficient ability of relative clause. No one students out of 30 students who showed poor ability of relative clauses. In the result of the study were used as the basses to assign level/grade to the subject under study, there are 12 students or $40 \%$ out of 40 students under investigation who fail in learning and acquiring relative clauses. It means that $40 \%$ of them still have low ability in mastering relative clauses.

\section{REFERENCES}

Ary, Donald. Cheser, Lucy Jacobs.

Sorensen, Chris. 2010.

Introduction to Research in

Education. United States:

Wadsworth Chang Learning.

Azar, Betty Scrampfer. 2002.

Understanding and Using English

Grammar. New York: Longman

Brown, H. Douglas. 2004. Principles of Language Learning and Teaching, Fourth Edition. New York: Pearson Education.

Cohen, Louis. 2000. Research Method in Education. London:

RoutledgeFalmer

Hewings, Martin. 2002. Advance Grammar in Use. New York. Chambridge University Press.

Dutwin, Phyllis. 2010. English Grammar Demystified. Chicago:The MacGrow-Hills Company. 